\title{
Chondrosarcoma mimicking an adnexal mass: A very rare case report
}

\section{Adneksiyal kitleyi taklit eden kondrosarkom: Çok nadir bir olgu}

\section{sunumu}

\author{
Hüseyin Çağlayan Özcan1 ${ }^{1}$, Aynur Mustafa1, Zehra Bozdağ², Seyhun Sucul1, Özcan Balat ${ }^{1}$ \\ ${ }^{1}$ Gaziantep University Faculty of Medicine, Department of Obstetrics and Gynecology, Gaziantep, Turkey \\ ${ }^{2}$ Gaziantep University Faculty of Medicine, Department of Pathology, Gaziantep, Turkey
}

\begin{abstract}
Chondrosarcoma is considered as a common primary bone sarcoma. These sarcomas can form large masses without any specific symptoms because there are no barriers in pelvic anatomy to prevent the enlargement of tumors, and can mimic ovarian masses. We present a pelvic chondrosarcoma in a woman aged 37 years who was misdiagnosed as having an ovarian mass due to the limited information obtained from imaging studies. Pelvic chondrosarcoma should be considered in patients who have pelvic masses with solid components. It should be kept in mind that interventions should be performed at centers where there are orthopedic surgeons with experience of this subject.
\end{abstract}

Keywords: Chondrosarcoma, diagnostic errors, ovarian mass

$\ddot{O} z$

Kondrosarkom primer kemik sarkomların en yaygın çeşidi olarak bilinir. Bu sarkomlar önlerinde büyümesini engelleyecek bir bariyer olmadığı için, herhangi spesifik bir semptom vermeden çok büyük boyutlara ulaşabilir ve ovaryan kitleleri taklit edebilirler. Otuz yedi yaşında pelvik kondrosarkom olan kadın hastada kısıtlı görüntüleme bilgilerine dayanarak ovaryan kitle olarak yanlış teşhis edilmiş bir hastayı sunduk. Solid komponentli pelvik kitlesi olan hastalarda pelvik sarkomlar da akla getirilmelidir. Şu iyi bilinmelidir ki; bu tür hastalara yapılan müdahaleler bu işte deneyimli ortopedik cerrahları olan merkezler tarafından yapılmalıdır.

Anahtar Kelimeler: Kondrosarkom, tanısal hatalar, ovaryan kitleleri

\section{Introduction}

Chondrosarcoma is considered as a common primary bone sarcoma, which is ranked as the third primary bone malignancy. One in five cases of bone sarcomas are due to chondrosarcoma, and half of all cases affect the pelvis(1). Moreover, this tumor arises predominantly after the second decade with a peak in the middle-aged period. Many heterogeneous groups of neoplasms are related to chondrosarcoma and cartilage matrix production is a typical feature of this tumor(2). These sarcomas form large masses without any specific symptoms because there are no barriers in the pelvic anatomy to prevent the enlargement of tumors(3). In this case report, we present a patient who had a tumor of undefined origin according to preoperative imaging methods, and a pelvic chondrosarcoma mimicking an adnexal mass. To the best of our knowledge, this is only the third case of pelvic chondrosarcoma in the English literature of obstetrics and gynecology.

\section{Case Report}

A 37-year-old single woman presented to our clinic with symptoms of pelvic pain, abdominal distension, and vaginal bleeding. During the pelvic examination, a mass that filled the pelvis was detected. The carcinoma antigen 125 (CA125) level was $40 \mathrm{U} / \mathrm{mL}$. Ultrasonographic and magnetic resonance imaging (MRI) examinations revealed a solid mass $20 \times 10 \mathrm{~cm}$ in diameter including calcified areas, and a mass consistent with myoma of $3.5 \mathrm{~cm}$ in diameter was observed in the cervico-isthmic region of the uterus. The endometrial thickness was $8 \mathrm{~mm}$ (Figure 1). During surgery, a mass of $18 \times 8 \mathrm{~cm}$ was observed that was displacing the uterus and extending from the symphysis pubis to the pelvis with a myoma of 3.5

Address for Correspondence/Yazışma Adresi: Aynur Mustafa, MD,

Gaziantep University Faculty of Medicine, Department of Obstetrics and Gynecology, Gaziantep, Turkey

Phone: +90 5511049770 E-mail: dr.aynur.moustafa@hotmail.com

Received /Geliş Tarihi: 03.10.2016 Accepted/Kabul Tarihi: 14.02.2017

${ }^{\oplus}$ Copyright 2017 by Turkish Society of Obstetrics and Gynecology

Turkish Journal of Obstetrics and Gynecology published by Galenos Publishing House. 
$\mathrm{cm}$ in diameter, posterior to the uterus corpus. The ovaries were normal on inspection. Specialists from the urology and orthopedics departments were consulted intraoperatively and it was decided that the tumor originated from the pelvic bone. Partial resections with myomectomy were performed because the tumor could not be completely removed (Figure 2). The postoperative pathologic examination was reported as grade 1, well-differentiated chondrosarcoma (Figure 3). The orthopedics department requested computerized tomography

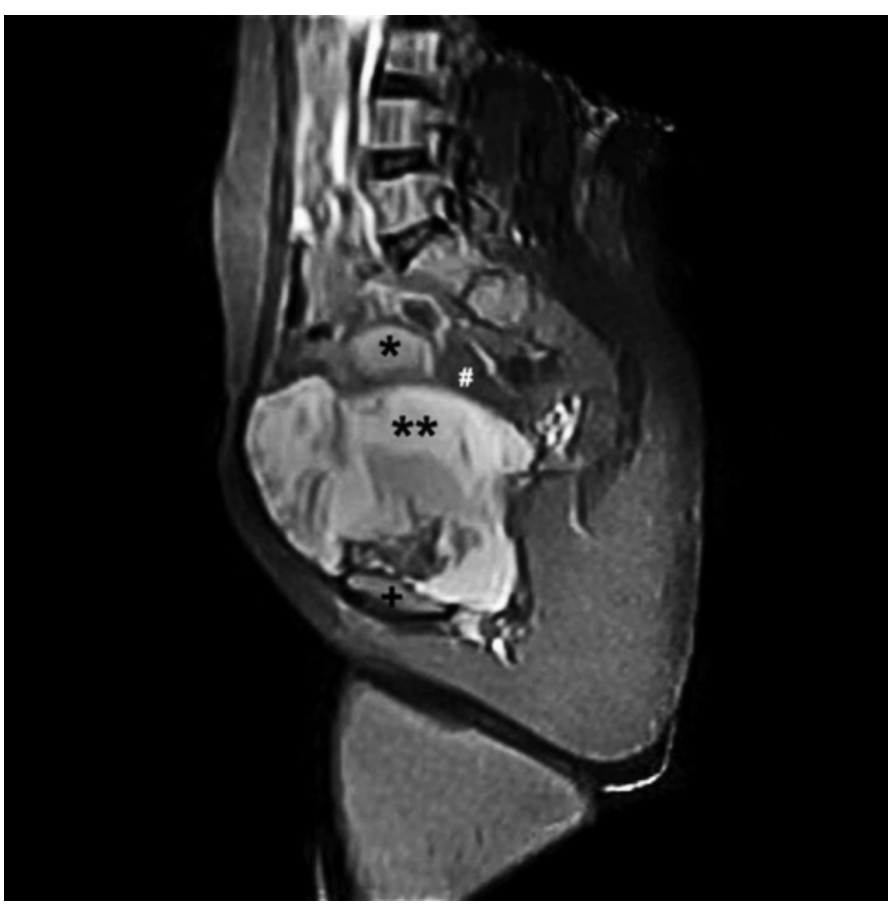

Figure 1. Magnetic resonance imaging showing a solid mass with $20 \times 10 \mathrm{~cm}$ in diameter including calcified areas, and a mass consistent with myoma of $3.5 \mathrm{~cm}$ in diameter was observed in the cervico-isthmic region of the uterus

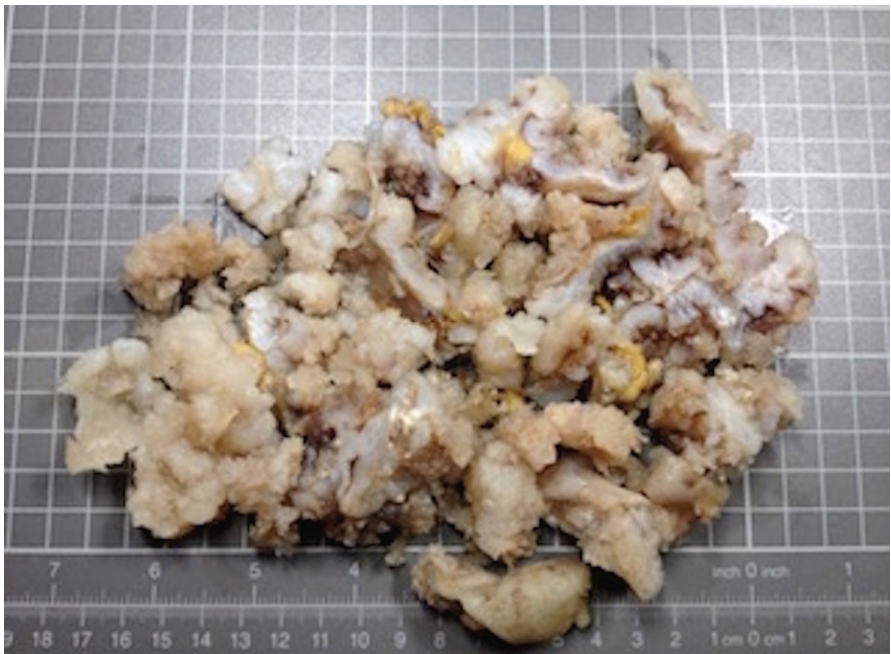

Figure 2. The macroscopic appearance of the lesion, which is seen in pieces, and has the solid-brilliant cartilaginous appearance of cross-sectional surface
(CT) imaging, which revealed masses consistent with metastasis in the liver, and a 9x8 cm diameter mass in the pubic area. The patient was referred to another healthcare unit because a skilled orthopedics team with experience of pelvic chondrosarcoma was unavailable.

\section{Discussion}

That a pelvic chondrosarcoma could masquerade as an ovarian mass was considered the peculiar part of our case. This camouflage exposes the limited role of imaging techniques and tumor markers in diagnosing pelvic tumors. Generally, chondrosarcoma has a silent course due to the special pelvic structure, which allows masses to grow feasibly without any boundaries and only become symptomatic after enlarging enough, as in our case. Thus, this tumor has a larger size in comparison with other pelvic masses when the diagnosis was established; the mean size is commonly $11 \mathrm{~cm}^{(4)}$. After reviewing all operated cases of pelvic mass in our department within the last 15 years, chondrosarcoma was the only case that was misdiagnosed as an ovarian mass, which reflects the sporadic incidence of this condition. Although all available imaging techniques, even CT and MRI, were used to assist us in mapping this tumor, we could not identify the exact margins, neither the exact organ from which this tumor derived. Moreover, the elevated CA125 was another misleading factor that increased our suspicion of ovarian mass. The surgical management of chondrosarcoma is a destructive operation for orthopedic surgeons due to the following principles: increased risk of vital organ injuries, high susceptibility to damage pelvic structural stability, challenging anatomic interactions of the pelvis, and devastating extension of the tumor. The mass could not be completely removed and the patient was considered as non-resectable and referred to another orthopedics clinic because we did not have an orthopedic surgical team skilled

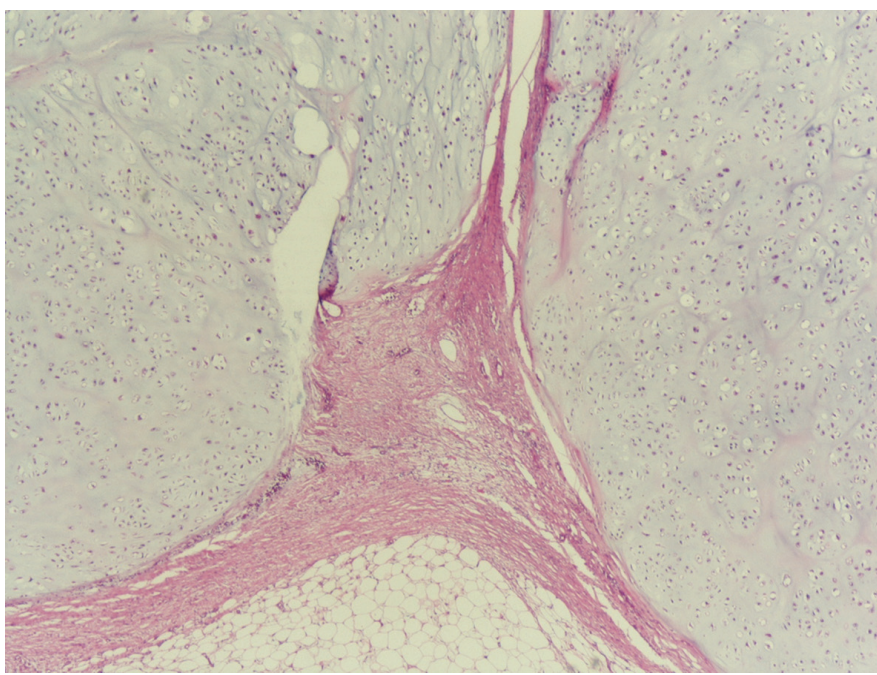

Figure 3. Microscopic appearance of the lesion, which was separated by fibrous septa, and was formed by nodular infiltrating, atypical chondrocytes, hematoxylin and eosin $x 40$ 
in pelvic chondrosarcoma. Vast majority of chondrosarcoma become symptomatic after reaching a large size and this can be explained by the slow growth rate of this these tumors(5). Grade 1 chondrosarcomas consist of profuse hyaline cartilage matrix surrounding a little cellular mass and metastasize infrequently(1). In our case, the pathologic result was grade 1 chondrosarcoma, and there were metastatic lesions observed in the liver in abdominal tomography. Pelvic chondrosarcomas can appear in various pathologic neoplasms, other than pure chondrosarcoma arising from the pelvic bone, such as chondrogenic tumors of the ovaries or heterologous carcinosarcomas of the uterus. However, all mentioned types have very low incidence rates(6). Moreover, mixed mesodermal tumors, commonly called carcinosarcoma, another manifestation of chondrosarcoma, are the most common heterologous sarcomas, originating from the uterus in most cases. The histologic appearance is a mixture of ectoderm and mesoderm-derived tissues. Either homologous or heterologous mesodermal tissue can be commonly found to be high grade. Heterologous tumors consist of a differentiated mesenchymal component accompanied by endometrial, stromal or undifferentiated sarcomas. Occasionally, these uterine tumors may enlarge and convert to giant pelvic masses that can destroy the uterine structure to the point where it can become unrecognizable(7). The cornerstone of treatment in managing this tumor is wide surgical excision, that still first line treatment ${ }^{(8)}$. After performing extensive intralesional curettage, local adjuvant treatment has encouraging long-term outcomes and adequate control of local recurrence in low-grade chondrosarcomas. Local adjuvant treatment is only effective in cases with well-defined boundaries with no extension beyond the bone(9). However, giant tumor or pelvic localization of chondrosarcoma can alter the treatment method, even in lowgrade conditions, as in our case, which require wide resection as a first-line management, rather than intralesional curettage(1).

\section{Conclusion}

Pelvic chondrosarcoma should be considered in patients who have pelvic masses with solid components because preoperative evaluations (imaging studies, pelvic examination) in daily practice may be inadequate for the diagnosis of pelvic masses. As a consequence, it should be kept in mind that interventions should be performed at centers where there are orthopedic surgeons with experience of this subject.

\section{Ethics}

Informed Consent: Consent form was filled out by all participants.

Peer-review: External and internal peer-reviewed.

\section{Authorship Contributions}

Surgical and Medical Practices: H.Ç.Ö., Ö.B., Concept: Z.B., Design: H.Ç.Ö., Data Collection or Processing: Z.B., S.S., Analysis or Interpretation: S.S., Literature Search: A.M., Writing: A.M.

Conflict of Interest: No conflict of interest was declared by the authors.

Financial Disclosure: The authors declared that this study received no financial support.

\section{References}

1. Gelderblom H, Hogendoorn PC, Dijkstra SD, van Rijswijk CS, Krol AD, Taminiau AH et al. The clinical approach towards chondrosarcoma. Oncologist 2008;13:320-9.

2. Wirbel RJ, Schulte M, Maier B, Koschnik M, Mutschler WE. Chondrosarcoma of the pelvis: oncologic and functional outcome. Sarcoma 2000;4:161-8.

3. Ozaki T, Hillmann A, Lindner N, Blasius S, Winkelmann W. Chondrosarcoma of the pelvis. Clin Orthop Relat Res 1997;337:22639.

4. Bergh P, Gunterberg B, Meis-Kindblom JM, Kindblom LG. Prognostic factors and outcome of pelvic, sacral, and spinal chondrosarcomas: a center-based study of 69 cases. Cancer 2001;91:1201-12.

5. Deloin X, Dumaine V, Biau D, Karoubi M, Babinet A, Tomeno B, et al. Pelvic chondrosarcomas: surgical treatment options. Orthop Traumatol Surg Res 2009;95:393-401.

6. Ki EY, Park JS, Mun JB, Hur SY. Primary ovarian malignant mixed mesodermal tumor: report of four cases. Eur J Gynaecol Oncol 2014;35:584-8.

7. Singh R. Review literature on uterine carcinosarcoma. J Can Res Ther 2014;10:461-8.

8. Pring ME, Weber KL, Unni KK, Sim FH. Chondrosarcoma of the pelvis. A review of sixty-four cases. J Bone Joint Surg Am 2001;83:1630-42.

9. Leerapun T, Hugate RR, Inwards CY. Surgical management of conventional grade I chondrosarcoma of long bones. Clin Orthop Relat Res 2007;463:166-72. 